\title{
Prognostic utility of ${ }^{99 \mathrm{~m}} \mathrm{Tc}-\mathrm{MIBI}$ single-photon emission computed tomography (SPECT) in post-myocardial infarction patients
}

\section{Wartość prognostyczna scyntygrafii perfuzyjnej mięśnia sercowego metodą SPECT $z$ użyciem ${ }^{99 m}$ Tc-MIBI w grupie pacjentów po przebytym w przeszłości zawale serca}

\author{
Ewelina Kowalczyk ${ }^{1}$, Dominika Filipiak-Strzecka ${ }^{1}$, Piotr Hamala ${ }^{1}$, Nina Śmiech ${ }^{1}$, \\ Jarosław D. Kasprzak ${ }^{1}$, Jacek Kuśmierek ${ }^{2}$, Anna Płachcińska ${ }^{3}$, Piotr Lipiec ${ }^{1}$ \\ ${ }^{1}$ Department of Cardiology, Medical University of Lodz, Poland \\ ${ }^{2}$ Department of Nuclear Medicine, Medical University of Lodz, Poland \\ ${ }^{3}$ Department of Quality Control and Radiological Protection, Medical University of Lodz, Poland
}

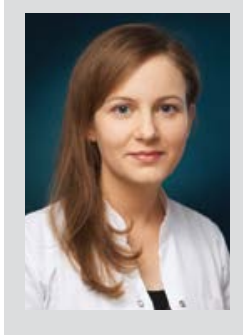

Lekarz Ewelina Kowalczyk jest absolwentką Wydziału Lekarskiego Uniwersytetu Medycznego w Łodzi. Obecnie odbywa szkolenie specjalizacyjne w Klinice Kardiologii Wojewódzkiego Specjalistycznego Szpitala im. dr. Władysława Biegańskiego w Łodzi pod kierownictwem prof. dr. hab. n. med. Jarosława D. Kasprzaka. Jej rozprawa doktorska dotyczy charakterystyki funkcji śródbłonka naczyniowego oraz funkcji mięśnia sercowego z zastosowaniem zaawansowanych metod echokardiograficznych w grupie młodych dorosłych chorych na cukrzycę typu 1. Zainteresowania medyczne skupia na diagnostyce nieinwazyjnej chorób układu sercowo-naczyniowego. Wolny czas spędza z dwójką dzieci.

\section{Abstract}

Introduction. Data describing prognostic utility of SPECT (single-photon emission computed tomography) among patients with history of myocardial infarction (MI) is scarce. We aimed to compare prognostic value of SPECT scans in patients with vs. without history of myocardial infarction (MI) prior to perfusion imaging.

Material and methods. 151 consecutive patients with history of myocardial infarction, who underwent exercise ${ }^{99 \mathrm{~m}} \mathrm{TC}-\mathrm{MIBI}$ SPECT examination were enrolled in the study (group 1). Next, based on clinical and demographic baseline characteristics, SPECT result and duration of follow-up period, a matching control subgroup (group 2) of 151 patients without history of MI was formed. During a mean follow-up of $60 \pm 15$ months in group 1 and a mean follow-up of $60 \pm 13.5$ months in group 2, we analyzed prevalence of cardiovascular events rates (cardiac deaths, myocardial infarctions and cardiac revascularizations). Results. We observed the following rates of cardiac deaths, myocardial infarctions and cardiac revascularizations: $4 \%$, $15 \%$ and $26 \%$, respectively in group 1 and $1 \%, 13 \%$ and $17 \%$, respectively in group 2 . In patients without history of MI (group 2) presence of mixed perfusion defects on SPECT was associated with significantly higher rate of myocardial infarctions $(p=0.05)$, hospitalizatons $(p=0.0001)$ and revascularizations $(p=0.0002)$. Fixed perfusion defects were associated with significantly higher occurrence of deaths $(p=0.012)$ and hospitalizations $(p=0.02)$, but not myocardial infarctions ( $p=0.52$ ) or cardiac revascularizations ( $p=0.10)$. In contrast, among patients with history of MI (group 1 ) there was no statistically significant relationship between any type of perfusion defects and cardiovascular events. Conclusions. Long term follow-up demonstrates that prognostic value of ${ }^{99 \mathrm{~m}} \mathrm{TC}-\mathrm{MIBI}$ SPECT is different in patients with and without history of MI.

Key words: myocardial infarction, prognosis, myocardial perfusion, SPECT

Folia Cardiologica 2017; 12, 5: 447-452

Address for correspondence: lek. Ewelina Kowalczyk, Department of Cardiology, Bieganski Hospital, Medical University of Lodz, Kniaziewicza 1/5, 91-347 Lodz, Poland, tel./faks +48 4265399 09, e-mail: e.kowalczyk@o2.pl 


\section{Introduction}

Over the past two decades advances in the clinical management of myocardial infarction (MI) have improved overall patients' survival $[1,2]$. As the population of post-MI patients increases, more information about cardiovascular risk stratification in this patient population is needed in our clinical practice.

Single-photon emission computed tomography (SPECT) myocardial perfusion imaging is a widely used non-invasive modality with well-established prognostic value [3, 4]. However, the data documenting its prognostic value are based mainly on the populations with suspected or known coronary artery disease. Whether similar prognostic value can be expected in patients with history of MI remains unclear.

The aim of our study is to compare a prognostic utility of SPECT between patients with and without past history of myocardial infarction prior to perfusion imaging.

\section{Material and methods}

\section{Study population}

151 consecutive patients with documented history of MI who underwent ${ }^{99 \mathrm{~m}} \mathrm{Tc}-\mathrm{MIBI}$ SPECT examination were included in the study. Patients who had MI within 6 months prior to the SPECT examination were not enrolled. All patients suffered from angina and were referred for the examination by the attending physicians. Subsequently, the control group of 151 patients without history of Ml were matched one to one according to baseline demographic and clinical characteristics (age, sex, left ventricle ejection fraction, history of hypertension and diabetes), SPECT scan result (normal, induced, mixed or fixed defects) and duration of follow-up time. The baseline characteristics of both groups are shown in Table 1.

\section{SPECT protocol}

All patients underwent stress-rest myocardial perfusion SPECT using two-day protocol. On the first day, patients underwent treadmill exercise test and received intravenously ${ }^{99 m} \mathrm{Tc}$-methoxyisobutylisonitrile (weight adjusted dose of 11 $\mathrm{MBq} / \mathrm{kg}$ ) at the peak of exercise. Imaging data were recorded using a circular $180^{\circ}$ acquisition (from $45^{\circ}$ left anterior oblique to $45^{\circ}$ right posterior oblique) for 64 projections at $20 \mathrm{~s} /$ projection. On the second day the same dose of the radiotracer was administered at rest and resting images were obtained as described above. SPECT perfusion studies were reconstructed using a filtered back projection method, without attenuation correction. Series of tomograms were assessed visually by experienced observers and with the Cedar Sinai algorithm based on polar maps. Based on the SPECT scan results the myocardial perfusion were classified as: normal (without perfusion abnormalities), with inducible defect(s) (reversible, stress-induced ischemia), mixed (irreversible ischemia + reversible), or fixed (irreversible) defect(s).

\section{Clinical follow-up}

The clinical follow-up regarding cardiovascular events was obtained by reviewing patients' records and telephone interviews. The following end-points were included in the analysis: cardiac deaths, myocardial infarctions, revascularizations (including percutaneous transluminal coronary angioplasty and coronary artery bypass graft) and cardiac hospitalizations. The revascularizations performed within 3 months from SPECT examination were not included in the analysis.

\section{Statistical analysis}

The data was tested for normal distribution using the D'Agostino-Pearson test. Continuous variables are pre-

Table 1. Baseline characteristics of study population. Data is presented as arithmetic mean \pm standard deviation or percentage (number of patients)

\begin{tabular}{|c|c|c|}
\hline & Group 1 (151 pts) & Group 2 (151 pts) \\
\hline Male & $57 \%$ (86 pts) & $57 \%$ (86 pts) \\
\hline Mean age (years) & $59 \pm 9.4$ & $59 \pm 8.6$ \\
\hline Mean follow-up duration (months) & $60 \pm 15$ & $60 \pm 13.5$ \\
\hline Left ventricle ejection fraction [\%] & $55 \pm 11$ & $55 \pm 7$ \\
\hline Hypertension & $50 \%$ (75 pts) & $50 \%$ (76 pts) \\
\hline Diabetes & 9\% (14 pts) & $10 \%$ (15 pts) \\
\hline \multicolumn{3}{|l|}{ Patients with following SPECT results: } \\
\hline - normal & & $21 \%$ (31 pts) \\
\hline - induced & & $20 \%$ (30 pts) \\
\hline - mixed & & $34 \%$ (52 pts) \\
\hline - $\quad$ fixed & & $25 \%$ (38 pts) \\
\hline
\end{tabular}


sented as an arithmetic mean and \pm standard deviation or median with minimum and maximum value. The association between type of perfusion defect and mentioned endpoints during follow-up period was assessed by performing a Kaplan-Meier survival analysis. Also, hazard ratios for cardiovascular endpoinsts were calculated for each perfusion defect. Results were considered as statistically significant if $p \leq 0.05$. All calculations were performed with MedCalc version 10.4.8.0 statistical software package (MedCalc, Belgium).

\section{Results}

The median time from myocardial infarction to SPECT examination in group 1 was 4 years (range from 0.5 to 16 years). After a mean follow-up period of $60 \pm 15$ months (group 1) and $60 \pm 13.5$ (group 2) the following rates of cardiac deaths, myocardial infarctions and cardiac revascularizations were observed: $4 \%, 15 \%$ and $26 \%$, respectively in group 1 and 1\%, 13\% and 17\%, respectively in group 2 .

In patients without history of MI (group 2) presence of mixed perfusion defects on SPECT was associated with significantly higher risk of myocardial infarctions $(p=0.05)$, hospitalizatons $(p=0.0001)$ and revascularizations $(p=$ 0.0002 ) (Table 2). Fixed perfusion defects were associated with significantly higher occurrence of deaths ( $p=0.012)$ and hospitalizations ( $p=0.02$ ), but not myocardial infarctions $(p=0.52)$ or cardiac revascularizations $(p=0.10)$.
In contrast, among patients with history of MI (group 1) there was no statistically significant relationship between any type of perfusion defects and cardiovascular events (Table 3).

\section{Discussion}

Our study proved that prognostic utility of SPECT scans are different for patients with and without prior history of MI (regardless the similar baseline characteristic).

Data from nationwide registries concerning patients' outcome after MI showed, that even $10 \%$ of patients had recurrent $\mathrm{Ml}$ during the first 3 years $[2,5]$ and $17 \%$ required subsequent revascularization during 5 years [6]. Thus, the prediction of adverse events in individuals after $\mathrm{Ml}$ is necessary.

To date, majority of studies concerning prognostic utility of SPECT imaging have been conducted on patients with known or suspected coronary artery disease (CAD). Based on this evidence, reversible defects are associated with MI and fixed defects (irreversible defects) are associated with cardiac deaths [7]. These findings are in agreement with our observations among patients without history of MI (group 2 ). In this group mixed perfusion defects were associated with cardiac revascularizations and myocardial infarctions, while fixed defects were associated with cardiac deaths. These conclusions cannot be strictly applied to patients with previous MI. Our study shows that among patients with

Table 2. Occurrence of cardiovascular end-points (cardiac death, cardiac hospitalization, myocardial infarction, revascularization) in patients from group 2 (without history of myocardial infarction prior the single-photon emission computed tomography examination) depending on the presence of various perfusion defects

\begin{tabular}{|c|c|c|c|c|}
\hline & $\begin{array}{c}\text { Inducible } \\
31 \mathrm{pts} \\
{[\%]} \\
\text { HR (95\% CI) } \\
\text { P value }\end{array}$ & $\begin{array}{c}\text { Mixed } \\
30 \mathrm{pts} \\
{[\%]} \\
\text { HR }(95 \% \mathrm{CI}) \\
\text { P value }\end{array}$ & $\begin{array}{c}\text { Fixed } \\
52 \text { pts } \\
{[\%]} \\
\text { HR }(95 \% \mathrm{Cl}) \\
\text { P value }\end{array}$ & $\begin{array}{c}\text { Normal perfusion } \\
38 \text { pts } \\
{[\%]} \\
\text { HR }(95 \% \mathrm{CI}) \\
\text { P value }\end{array}$ \\
\hline Cardiac death & $0 \%$ & $0 \%$ & $\begin{array}{c}4 \% \\
1.32(0.89-2.32) \\
0.05\end{array}$ & $0 \%$ \\
\hline Cardiac hospitalizations & $\begin{array}{c}47 \% \\
0.65 \\
(0.39-1.08) \\
0.12\end{array}$ & $\begin{array}{c}67 \% \\
2.35 \\
(1.41-3.9) \\
0.0001\end{array}$ & $\begin{array}{c}40 \% \\
0.69 \\
(0.41-1.16) \\
0.02\end{array}$ & $24 \%$ \\
\hline Myocardial infarction & $\begin{array}{c}10 \% \\
0.37 \\
(0.23-1.04) \\
0.15\end{array}$ & $\begin{array}{c}19 \% \\
2.4 \\
(0.91-6.3) \\
0.05\end{array}$ & $\begin{array}{c}16 \% \\
1.37 \\
(0.49-3.85) \\
0.52\end{array}$ & $5 \%$ \\
\hline Revascularizations & $\begin{array}{c}16 \% \\
0.52 \\
(0.22-1.25) \\
0.22\end{array}$ & $\begin{array}{c}37 \% \\
3.69 \\
(1.64-8.32) \\
0.0002\end{array}$ & $\begin{array}{c}13 \% \\
0.45 \\
(0.19-1.02) \\
0.10\end{array}$ & $5 \%$ \\
\hline
\end{tabular}

$\mathrm{HR}$ - hazard ratio; $\mathrm{Cl}$ - confidence interval 
Table 3. Occurrence of cardiovascular end-points (cardiac death, cardiac hospitalization, myocardial infarction, revascularization) in patients from group 1 (with history of myocardial infarction prior the single-photon emission computed tomography examination) depending on the presence of various perfusion defects

\begin{tabular}{|c|c|c|c|c|}
\hline & $\begin{array}{l}\text { Inducible } \\
\text { 31 pts } \\
{[\%]} \\
\text { HR (95\% CI) } \\
\text { P value }\end{array}$ & $\begin{array}{c}\text { Mixed } \\
30 \text { pts } \\
{[\%]} \\
\text { HR }(95 \% \mathrm{Cl}) \\
\text { P value }\end{array}$ & $\begin{array}{c}\text { Fixed } \\
52 \text { pts } \\
{[\%]} \\
\text { HR (95\% CI) } \\
\text { P value }\end{array}$ & $\begin{array}{c}\text { Normal } \\
38 \mathrm{pts} \\
{[\%]}\end{array}$ \\
\hline Cardiac death & $0 \%$ & $\begin{array}{c}8 \% \\
4.02 \\
(0.74-21.99) \\
0.08\end{array}$ & $\begin{array}{c}5 \% \\
1.47 \\
(0.23-9.21) \\
0.66\end{array}$ & $0 \%$ \\
\hline Cardiac hospitalization & $\begin{array}{c}57 \% \\
1.4 \\
(0.61-1.79) \\
0.88\end{array}$ & $\begin{array}{c}61 \% \\
1.52 \\
(0.94-2.48) \\
0.06\end{array}$ & $\begin{array}{c}57 \% \\
1.08 \\
(0.65-1.78) \\
0.75\end{array}$ & $34 \%$ \\
\hline Myocardial infarction & $\begin{array}{c}19 \% \\
1.17 \\
(0.41-3.32) \\
0.76\end{array}$ & $\begin{array}{c}23 \% \\
1.84 \\
(0.75-4.54) \\
0.14\end{array}$ & $\begin{array}{c}13 \% \\
1.42 \\
(0.68-2.96) \\
0.58\end{array}$ & $5 \%$ \\
\hline Revascularization & $\begin{array}{c}29 \% \\
1.21 \\
(0.55-2.65) \\
0.61\end{array}$ & $\begin{array}{c}29 \% \\
1.37 \\
(0.69-2.73) \\
0.32\end{array}$ & $\begin{array}{c}32 \% \\
1.42 \\
(0.68-2.96) \\
0.30\end{array}$ & $13 \%$ \\
\hline
\end{tabular}

pts - patients; $\mathrm{HR}$ - hazard ratio; $\mathrm{Cl}$ - confidence interval

prior history of MI, perfusion defects cannot discriminate future cardiovascular events. Regrettable, there is a lack of similar studies in post MI population with which we can compare our results.

A normal SPECT result is associated with an excellent very long term prognosis [8, 9], even among patients with past history of $\mathrm{MI}$ [8-10] or CAD confirmed by coronary angiography [11]. The annual hard event rate (cardiac death or nonfatal MI) for a normal SPECT result is about $0.6 \%$ while for an abnormal scan is 12 -fold higher [12]. The current study also confirms this observation.

\section{Study limitations}

This is a single-center study with a relatively small group of patients. Therefore, these results need to be validated in a larger, multi-center study. Another limitation is a lack of analysis of infarct and perfusion defects size. The assessment of extent of total perfusion abnormality, especially the extent of reversible (inducible) defects [13-15] or infarct size $[16,17]$ may enhance the predictive utility of SPECT.

\section{Conclusions}

The myocardial perfusion SPECT imaging remains a very useful tool for risk stratification among patients with known or suspected CAD and no MI history. However, our study shows, that predictive utility of SPECT among patients with pervious history of MI is limited.

\section{Conflict of interest(s)}

The authors declare no conflict of interest

\section{Streszczenie}

Wstęp. W dostępnej literaturze brakuje badań służących ocenie przydatności prognostycznej scyntygrafii perfuzyjnej mięśnia sercowego SPECT (tomografia emisyjna pojedynczego fotonu) w grupie chorych z wywiadem przebytego zawału serca. Celem opisanego badania jest porównanie wartości prognostycznej SPECT w grupie pacjentów z wywiadem zawału serca przed badaniem SPECT oraz bez takiego wywiadu. 
Materiał i metody. Do badania włączono 151 kolejnych pacjentów z wywiadem zawału serca, u których wykonano badanie SPECT z użyciem ${ }^{99 \mathrm{~m}}$ Tc-MIBI. Następnie, na podstawie charakterystyki klinicznej i demograficznej oraz długości okresu obserwacji dobrano, grupę kontrolną 151 pacjentów poddanych badaniu SPECT, bez wywiadu wcześniejszego zawału serca.

Wyniki. Po średnim okresie obserwacji $60 \pm 15$ miesięcy (grupa 1) i $60 \pm$ 13,5 miesiąca (grupa 2) częstość wystąpienia punktów końcowych, takich jak zgon z przyczyn sercowo-naczyniowych, zawał serca, rewaskularyzacja, wyniosła odpowiednio 4\%, 15\% i 26\% w grupie 1 oraz 1\%,13\%, 17\% w grupie 2. Wśród pacjentów bez wywiadu zawału serca (grupa 2) obecność mieszanych zaburzeń perfuzji w badaniu SPECT wiązała się z istotnie większą częstością zawałów serca ( $p$ $=0,05)$, hospitalizacji $(p=0,0001)$ oraz rewaskularyzacji $(p=0,0002)$. Utrwalone zaburzenia perfuzji wiązały się z istotnie większą liczbą zgonów z przyczyn sercowo-naczyniowych, liczbą hospitalizacji $(p=0,02)$, ale nie zawałów serca ( $p=$ $0,52)$ ani rewaskularyzacji $(p=0,10)$. Natomiast wśród pacjentów bez wywiadu zawału serca (grupa 1) nie zaobserwowano istotnej statystycznie zależności między typem zaburzeń perfuzji a występowaniem powyższych punktów końcowych.

Wnioski. W długoterminowej obserwacji wykazano różnicę w zakresie wartości rokowniczej badania SPECT między pacjentami po przebytym zawale serca oraz bez wywiadu zawału.

Słowa kluczowe: SPECT, zawał serca, rokowanie, scyntygrafia perfuzyjna

Folia Cardiologica 2017; 12, 5: 447-452

\section{References}

1. Okura N, Ogawa $\mathrm{H}$, Katoh J, et al. Long-term prognosis of patients with acute myocardial infarction in the era of acute revascularization (from the Heart Institute of Japan Acute Myocardial Infarction [HIJAMI] registry). Int J Cardiol. 2012; 159(3): 205-210, doi: 10.1016/j. ijcard.2011.02.072, indexed in Pubmed: 21402419.

2. Jernberg $\mathrm{T}$, Hasvold $\mathrm{P}$, Henriksson $\mathrm{M}$, et al. Cardiovascular risk in post-myocardial infarction patients: nationwide real world data demonstrate the importance of a long-term perspective. Eur Heart J. 2015; 36(19): 1163-1170, doi: 10.1093/eurheartj/ehu505, indexed in Pubmed: 25586123.

3. Montalescot G, Sechtem U, Achenbach S, et al. Task Force Members, ESC Committee for Practice Guidelines, Document Reviewers. 2013 ESC guidelines on the management of stable coronary artery disease: the Task Force on the management of stable coronary artery disease of the European Society of Cardiology. Eur Heart J. 2013; 34(38): 2949-3003, doi: 10.1093/eurheartj/eht296, indexed in Pubmed: 23996286.

4. Finn SD, Gardin JM, Abrams J, et al. 2012 ACCF/AHA/ACP/AATS/ PCNA/SCAI/STS guideline for the diagnosis and management of patients with stable ischemic heart disease: a report of the American College of Cardiology Foundation/American Heart Association Task Force on practice guidelines, and the American College of Physicians, American Association for Thoracic Surgery, Preventive Cardiovascular Nurses Association, Society for Cardiovascular Angiography and Interventions, and Society of Thoracic Surgeons. J Am Coll Cardiol. 2012; 60: e44-e164.

5. Kern DM, Mellström C, Hunt PR, et al. Long-term cardiovascular risk and costs for myocardial infarction survivors in a US commercially insured population. Curr Med Res Opin. 2016; 32(4): 703-711, doi: 10.1185/03007995.2015.1136607, indexed in Pubmed: 26709864.

6. Fox KAA, Carruthers KF, Dunbar DR, et al. Underestimated and under-recognized: the late consequences of acute coronary syndrome (GRACE UK-Belgian Study). Eur Heart J. 2010; 31(22): 2755-2764, doi: 10.1093/eurheartj/ehq326, indexed in Pubmed: 20805110.
7. Elhendy A, Schinkel AFL, van Domburg RT, et al. Prognostic significance of fixed perfusion abnormalities on stress technetium-99m sestamibi single-photon emission computed tomography in patients without known coronary artery disease. Am J Cardiol. 2003; 92(10): 1165-1170, doi: 10.1016/j.amjcard.2003.07.024, indexed in Pubmed: 14609590.

8. Schinkel AFL, Boiten HJ, van der Sijde JN, et al. 15-year outcome after normal exercise ${ }^{99} \mathrm{mTc}$-sestamibi myocardial perfusion imaging: what is the duration of low risk after a normal scan? J Nucl Cardiol. 2012; 19(5): 901-906, doi: 10.1007/s12350-012-9587-9, indexed in Pubmed: 22678852.

9. Schinkel AFL, Elhendy A, Bax JJ, et al. Prognostic implications of a normal stress technetium-99m-tetrofosmin myocardial perfusion study in patients with a healed myocardial infarct and/or previous coronary revascularization. Am J Cardiol. 2006; 97(1): 1-6, doi: 10.1016/j. amjcard.2005.07.102, indexed in Pubmed: 16377272.

10. Zhang $X$, Liu X, He ZX, et al. Long-term prognostic value of exercise 99mTc-MIBI SPET myocardial perfusion imaging in patients after percutaneous coronary intervention. Eur J Nucl Med Mol Imaging. 2004; 31(5): 655-662, doi: 10.1007/s00259-003-1407-7, indexed in Pubmed: 14740177.

11. Yang MF, Dou KF, Liu XJ, et al. Prognostic value of normal exercise 99mTc-sestamibi myocardial tomography in patients with angiographic coronary artery disease. Nucl Med Commun. 2006; 27(4): 333-338, doi: 10.1097/01.mnm.0000202865.59670.1b, indexed in Pubmed: 16531918.

12. Iskander S, Iskandrian AE. Risk assessment using single-photon emission computed tomographic technetium-99m sestamibi imaging. J Am Coll Cardiol. 1998; 32(1): 57-62, doi: 10.1016/s07351097(98)00177-6, indexed in Pubmed: 9669249.

13. Schinkel AFL, Elhendy A, van Domburg RT, et al. Incremental value of exercise technetium-99m tetrofosmin myocardial perfusion single-photon emission computed tomography for the prediction of cardiac events. Am J Cardiol. 2003; 91(4): 408-411, doi: 10.1016/ s0002-9149(02)03234-4, indexed in Pubmed: 12586253. 
14. Iskandrian AS, Chae SC, Heo J, et al. Independent and incremental prognostic value of exercise single-photon emission computed tomographic (SPECT) thallium imaging in coronary artery disease. J Am Coll Cardiol. 1993; 22(3): 665-670, doi: 10.1016/0735-1097(93)90174-y, indexed in Pubmed: 8354796.

15. Boiten HJ, van der Sijde JN, Ruitinga PR, et al. Long-term prognostic value of exercise technetium-99m tetrofosmin myocardial perfusion single-photon emission computed tomography. J Nucl Cardiol. 2012; 19(5): 907-913, doi: 10.1007/s12350-012-9585-y, indexed in Pubmed: 22875719.
16. Elhendy A, Schinkel AFL, van Domburg RT, et al. Prognostic value of stress Tc-99m tetrofosmin SPECT in patients with previous myocardial infarction: impact of scintigraphic extent of coronary artery disease. J Nucl Cardiol. 2004; 11(6): 704-709, doi: 10.1016/j.nuclcard.2004.08.006, indexed in Pubmed: 15592194.

17. Zellweger MJ, Dubois EA, Lai S, et al. Risk stratification in patients with remote prior myocardial infarction using rest-stress myocardial perfusion SPECT: prognostic value and impact on referral to early catheterization. J Nucl Cardiol. 2002; 9(1): 23-32, doi: 10.1067/ mnc.2002.118925, indexed in Pubmed: 11845126. 